\title{
Immunohistochemical and clinicopathological study of non-Hodgkin's lymphoma in Erbil, Kurdistan
}

\begin{tabular}{ccc}
\hline Tara Sirwan Kamil * & Rafal Abdul Razaq Al-rawi * & Maysoon Alhaideri * \\
\hline Abstract &
\end{tabular}

Background and objective: Non-Hodgkin lymphoma is a cancer of the lymphatic system. Types of non-Hodgkin lymphoma vary significantly in their severity from indolent to very aggressive. The aim of this study was to investigate the incidence, immunohistochemical expression, clinical and histopathological prognostic factors of patients with non-Hodgkin lymphoma.

Methods: A total of 59 patients with non-Hodgkin lymphoma cases were reviewed and investigated at Razgary Teaching Hospital in Erbil city during the period from January, 2011 to January, 2013. Data of patients were tabulated and distributed according to their age, sex, site, immunohistochemical expression and WHO classification.

Results: Age of non-Hodgkin lymphoma patients ranged from 2 to 88 years with a mean of 45 year. Around $49 \%$ of the patients were of age group over 50 years and $54.2 \%$ of patients were male. Immunohistochemical investigation indicated that $71.2 \%$ of non-Hodgkin lymphomas were of B cell type, the highest percentage $(33.3 \%)$ of them was of diffuse large cell type. While the T cell type was found in $20.3 \%$, the highest percentage $(33.3 \%)$ of them was of Anaplastic lymphoma. CD20 and CD3 showed more consistent and strong expression for $B$ and $T$ cells non-Hodgkin lymphoma, respectively. Results showed high BCL2 expression. Nodal non-Hodgkin lymphoma account for $50.8 \%$ of the total cases.

Conclusion: Most non-Hodgkin lymphomas were of $\mathrm{B}$ cell type and highest percentage is of diffuse large cell type. CD20 and CD3 were more reliable as an indicator of B and T cell lineage, respectively. Most non-Hodgkin lymphomas were of intermediate-high grade. Nodal site represent highest rate for primary non-Hodgkin lymphoma.

Keywords: Non-Hodgkin lymphoma, CD20 \& CD3.

\section{Introduction}

Non-Hodgkin lymphoma (NHL) is cancer of the lymphatic system, which represent a group of malignant lymphomas whose common feature is absence of the ReedSternberg cells characteristic of Hodgkin disease. Because lymphatic tissue is found in many parts of the body, NHL can start almost anywhere. ${ }^{1,2} \mathrm{NHL}$ is the $6^{\text {th }}$ among the commonest ten cancers in Iraq and constitutes $5.52 \%$ of all cancers in both genders ${ }^{3} \mathrm{NHL}$ is the $3^{\text {rd }}$ among the commonest ten cancers in Kurdistan Region in Iraq and constitutes $8.72 \%$ of all cancer in females and $12.46 \%$ in males. ${ }^{4} \mathrm{NHL}$ is the seventh most common cancer in the US, and age-adjusted incidence rose by more than $82.5 \%$ from 1975 to $2008 .^{5}$ There were an estimated 356000 new cases of $\mathrm{NHL}$ and 192000 deaths from NHL worldwide in $2008 .{ }^{6}$ There is a large variation in the geographical distribution of NHL types, with a higher proportion of follicular and diffuse lymphoma in North America and Europe, and a higher proportion of T-cell lymphoma in Asia. ${ }^{7}$ Part of the difference might be due to a greater variability in the incidence of B-cell NHL compared with T-cell NHL. $^{8}$ There are many types of NHL. Sometimes they are grouped as aggressive lymphomas, which are also called intermediate-grade and high-grade lymphomas. These cancers tend to grow and

* Department of Clinical Analysis, College of Pharmacy, Hawler Medical University, Erbil, Iraq. 
http://dx.doi.org/10.15218/zjms.2014.0029

spread quickly and cause severe symptoms. Nonaggressive lymphomas are also called indolent or low-grade lymphomas. These tend to grow and spread quite slowly and cause few symptoms. ${ }^{1-3}$ The World Health Organization (WHO) system of NHLs are classified as far as possible according to their normal counterparts in B or $\mathrm{T}$ lymphocyte lineage. In addition to its biological relevance, this system has direct clinical applicability and is becoming the accepted international standard. ${ }^{9}$ Moreover, the Working Formulation (WF) in 1982 classified NHLs into three histological categories (low grade, intermediate grade and high grade). ${ }^{10}$ The aim of this study is to detect the incidence, immunohistochemical expression as well as clinical and histopathological prognostic factors of patients with $\mathrm{NHL}$ in Erbil city, Kurdistan.

\section{Methods}

A retrospective review of 59 cases with $\mathrm{NHL}$ were retrieved from Razqari Teaching Hospital at Histopathology Laboratory during the period from January, 2011 to January, 2013 in Erbil city, Kurdistan, Iraq. Clinical information about gender, age, site of lesion were considered. Haematoxylin, eosin staining and immunohistochemical investigation with panel of antibodies consisted of CD20, CD3, CD79 a and BCL2 were obtained from the laboratory. Primary monoclonal antibody used is of purified liquid form. For the avidin-biotin complex $(A B C)$ detection system (secondary detection system), alkaline phosphatase method was used. The immunorecipient visualized as brown color in the cytoplasmic side of the cell membrane for all markers. Immunohistochemical staining for each antibody was recorded either positive/ negative, normal/abnormal, individual scattered cells/clusters, small/large cells, and percent of biopsy involved $(<1 \%, 1-$ $5 \%$, or $>5 \%$ ). ${ }^{11}$ The presence of clusters of cells was classified as abnormal (positive) when there were large number of clusters $(>5 \%)$, which express the antibodies. Data was analyzed using Chi square test of goodness of fit. A P value of less than 0.01 was considered highly significant and that less than 0.05 was considered statistically significant.

\section{Results}

Of 59 patients with NHL, 32 patients $(54.2 \%)$ were male, and 27 patients $(45.8 \%)$ were female (Table 1$)$. There was no significant difference between male and female patients. The age of NHL patients ranged from 2 to 88 years with a mean of 45 years. There was a highly significant difference among the age groups. The highest percentage of patients $(49.2 \%)$ were of age group of $>50$ years old. The lowest percentage of patients $(20.3 \%)$ were of age group of $\leq 25$ years old (Table $2)$. There were highly significant differences in the sites of NHL. The commonest primary site of $\mathrm{NHL}$ was lymph nodes (cervical, axillary and inguinal) which were found in 30 out 59 patients $(50.8 \%)$ followed by 12 patients $(20.3 \%)$ in bone marrow. Eight patients (13.6\%) were found in gastrointestinal tissues. Low percentages were found in retroperitoneal $(3.4 \%)$, brain $(3.4 \%)$ and nose (3.4\%) (Table 3 ). Majority of the patients (42 cases, $71.2 \%$ ) with $\mathrm{NHL}$ were of B cell type (Figure 2). T cell type constituted $20.3 \%$ (12 patients) (Figure 3 and Table 4). The percentages of different types of $B$ cells lymphoma were significantly different $(P<0.01)$ (Table 5$)$. Diffuse large $B$ cell type was counted in 4 patients (33.3\%). Eight patients (19.1\%) found to have small B cell lymphoma. Follicular lymphoma was diagnosed in 6 patients $(14.3 \%)$ while small noncleaved cell lymphoma (Burkitt lymphoma) was diagnosed in 3 patients $(7.1 \%)$. Table 6 presents the percentages of different types of $T$ cells, which show a highly significant difference $(P<0.01)$. Anaplastic lymphoma cell type was counted in 4 patients $(33.3 \%)$. Three patients $(25 \%)$ found to have peripheral $\mathrm{T}$ cell type. Three patients $(25 \%)$ found to have lymphoblastic lymphoma. The expression of CD20 was positive in 46 patients $(78 \%)$ and negative 
in 13 cases $(22 \%)$ the difference was highly significant $(P<0.01)$. The expression of CD79a was positive in 40 patients $(67.8 \%)$ and negative in 19 cases $(32.2 \%)$. The difference was highly significant $(P<0.01)$. The expression of CD3 was positive in 18 patients $(30.5 \%)$ and 41 patients
(69.5\%) with negative CD3 expression. The difference was highly significant $(P<0.01)$. The expression of BCL2 was negative in 39 patients $(66.1 \%)$ whereas positive BCL2 was found in 20 patients $(33.9 \%)$. The difference was highly significant $(P<0.01)$ as shown in Figure 1.

Table 1: Distribution of patients according to gender.

\begin{tabular}{lll}
\hline Gender & No. & $\%$ \\
\hline Male & 32 & 54.2 \\
Female & 27 & 45.8 \\
Total & 59 & \\
\hline
\end{tabular}

Table 2: Distribution of patients according to age.

\begin{tabular}{lll}
\hline Age groups (years) & No. & $\%$ \\
\hline$\leq 25$ & 12 & 20.3 \\
$26-50$ & 18 & 30.5 \\
$>50$ & 29 & 49.2 \\
Total & 59 & \\
\hline
\end{tabular}

Table 3: Distribution of patients according to site of tumor.

\begin{tabular}{lll}
\hline Site & No. & $\%$ \\
\hline lymph node (cervical, axillary and inguinal) & 30 & 50.8 \\
Bone marrow & 12 & 20.3 \\
Gastrointestinal tissue & 8 & 13.6 \\
Retroperitoneal tissue & 2 & 3.4 \\
Brain & 2 & 3.4 \\
Nose & 2 & 3.4 \\
Others & 3 & 5.1 \\
Total & 59 & \\
\hline
\end{tabular}

Table 4: Distribution of patients according to lymphocyte cell type.

\begin{tabular}{lll}
\hline Microscopical Examination & No. & $\%$ \\
\hline B-cell type & 42 & 71.2 \\
T-cell type & 12 & 20.3 \\
Others* & 5 & 8.5 \\
Total & 59 & \\
* Others include mixed type (non-specified lymphoma) & \\
\hline
\end{tabular}


Table 5: Distribution of cases according to B cell type neoplasm.

\begin{tabular}{lll}
\hline B cell type & No. & $\%$ \\
\hline Diffuse large B cell type (pure large and mixed type) & 14 & 33.3 \\
Small B cell lymphoma & 8 & 19.1 \\
Follicular lymphoma & 6 & 14.3 \\
Small noncleaved cell lymphoma (Burkitt lymphoma) & 3 & 7.1 \\
Others & 11 & 26.2 \\
Total & 42 & \\
\hline
\end{tabular}

Table 6: Distribution samples according to T cell neoplasm.

\begin{tabular}{lll}
\hline T cell type & No. & \% \\
\hline Anaplastic lymphoma & 4 & 33.3 \\
peripheral T cell type & 3 & 25 \\
Lymphoblastic lymphoma & 3 & 25 \\
Others* & 2 & 16.7 \\
Total & 12 & \\
*Others include unclassified type. & & \\
\hline
\end{tabular}

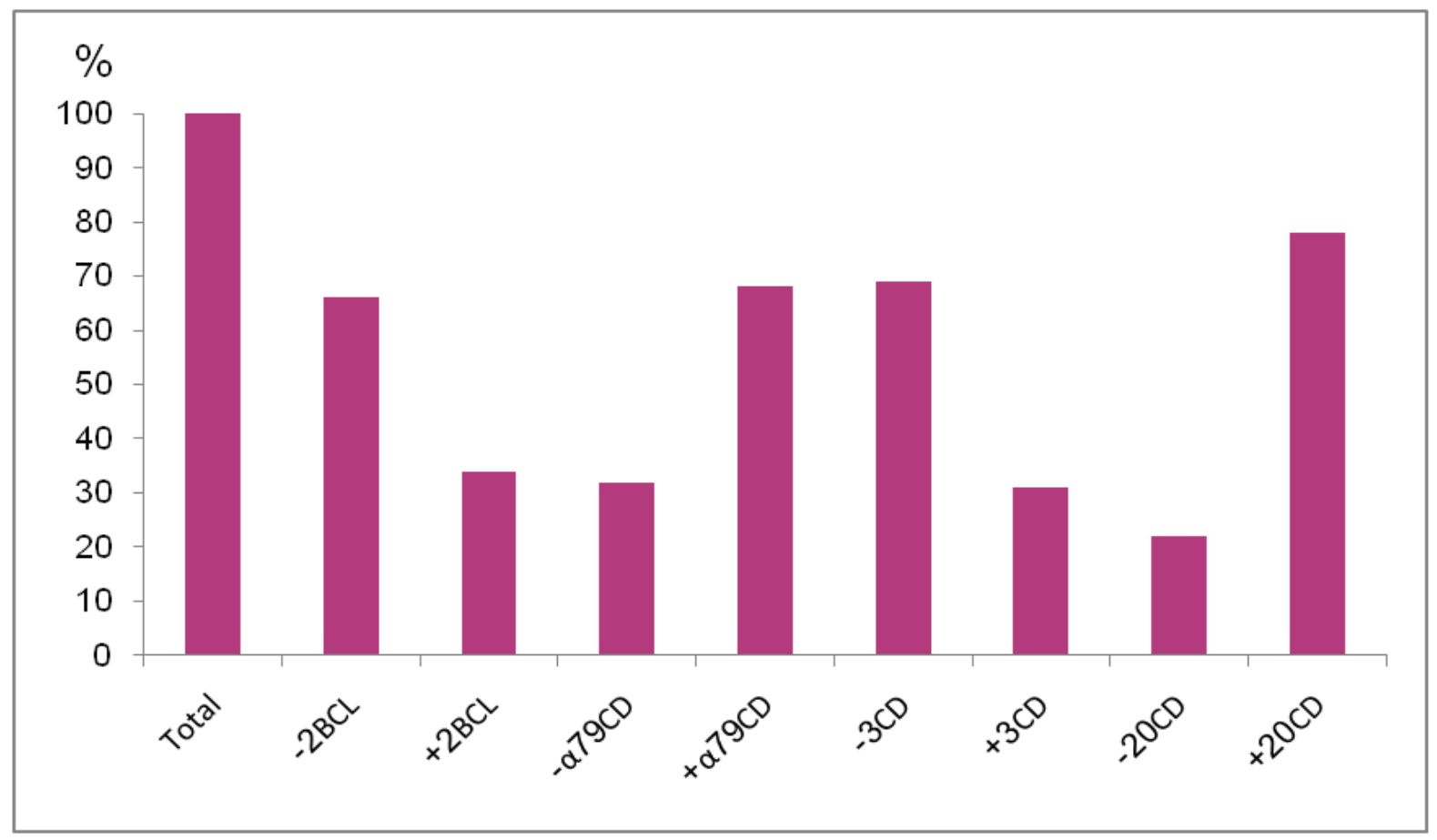

Figure 1: Histogram of percentages distribution of cases according to immunehistochemical expression. 


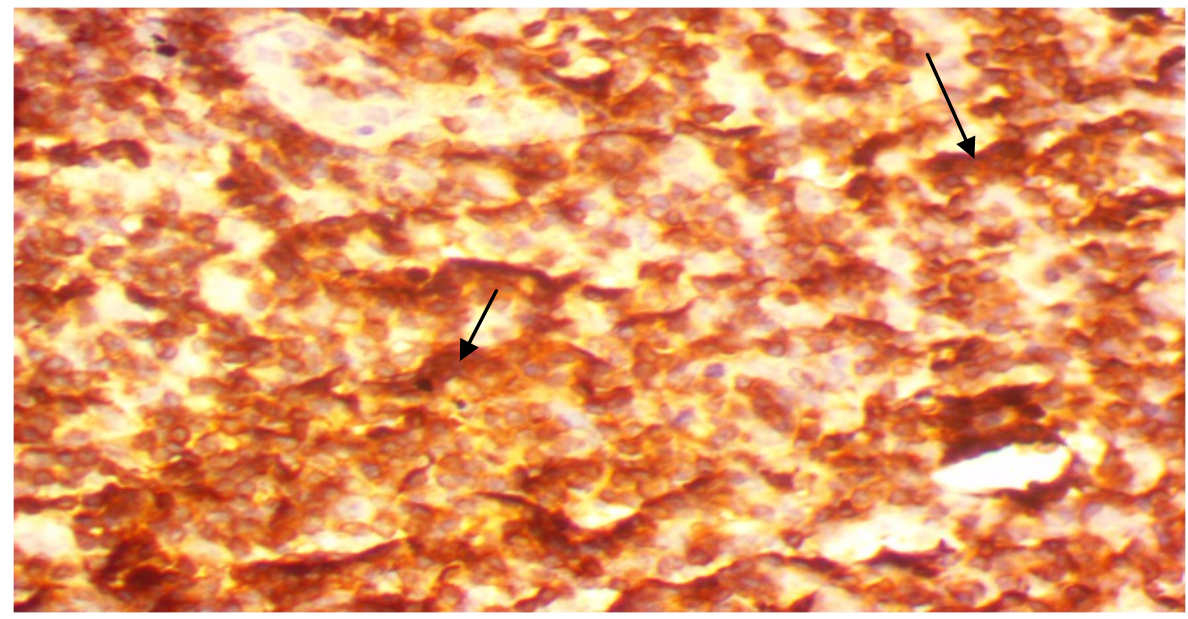

Figure 2: B cell type NHL shows positive reactivity for $\mathrm{CDr} \cdot$. Cytoplasmic side of the cell membrane stains with brown color (arrow). (X 400) (Immunohistochemical staining).

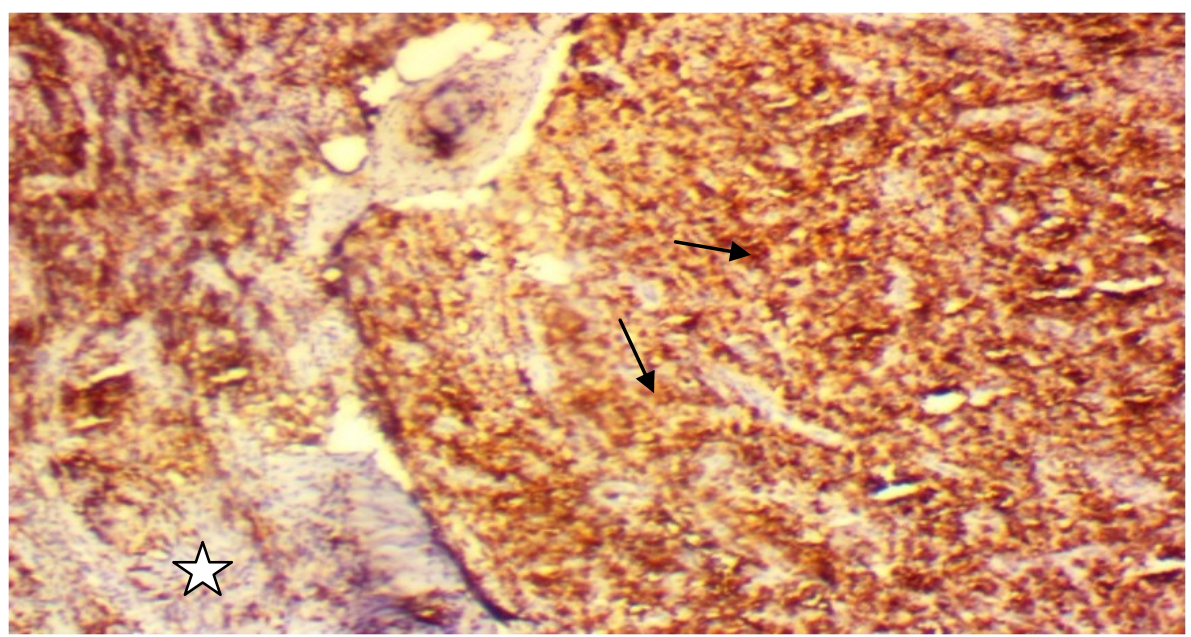

Figure 3: $\mathrm{T}$ cell type NHL shows positive reactivity for CDr. Cytoplasmic side of the cell membrane stains with brown color (arrow) while the adjacent area shows negative reactivity (star). (X 100) (Immunohistochemical staining).

\section{Discussion}

$\mathrm{NHL}$ is malignant tumor with lymphatic system origin. Many different types of $\mathrm{NHL}$ have been described. ${ }^{13}$ The current study revealed that males were marginally predominant $(54.2 \%)$ to females $(45.8 \%)$. This result had a similar trend with another study conducted in Sulaimania and Dohuk, Iraq, ${ }^{14}$ which reported $66.8 \%$ were male and $33.1 \%$ were female. Results revealed that the majority $(49.2 \%)$ of patients were of age group over 50 years which agreed by another study. ${ }^{14}$ The result of this study showed that $71.2 \%$ of all NHL was of B cell type while T cell type rate was $20.3 \%$. This result is similar to another study which showed $72 \%$ B cell expression, $22.5 \%$ T cell expression and $5.5 \%$ did not express any marker, ${ }^{15}$ while another study revealed that $91 \%$ of patients with $\mathrm{NHL}$ was of $\mathrm{B}$ cell type, while $\mathrm{T}$ cell type rate was $9 \% .{ }^{14}$ Among all patients with $\mathrm{B}$ cell type $\mathrm{NHL}$, the diffuse large cell was of the highest percentage $(33.3 \%)$. Results of another study reveled that diffused large cell type 
was the commonest $\mathrm{B}$ cell type $\mathrm{NHL}$ $(52.2 \%)$ followed by Burkitt's lymphoma $(14.6 \%) .^{14}$ In another study, B-cell diffuse large cell lymphoma (26\%) was found to be the predominant $B$ cell type. ${ }^{15}$ The current study showed that the most common type of $\mathrm{T}$ cell $\mathrm{NHL}$ was Anaplastic lymphoma $(33.3 \%)$, which is close to result $(26.3 \%)$ of another study. ${ }^{14}$ On the other hand, another study showed that the commonest T-cell lymphoma was $\mathrm{T}$ lymphoblastic lymphoma $(67 \%) .{ }^{15}$ This variation has been attributed to geographic and racial cause. ${ }^{16}$ This study showed that most NHLs were of intermediate-high grade. The results also showed extra nodal NHL accounted for $49.2 \%$ of the total cases. This is comparable to the rates observed in another study $(48.3 \%){ }^{14}$ Immunohistohemistry is an important technique in many challenging lymphoma cases. ${ }^{17}$ In this study a panel of antibodies consisted of CD20, CD3, CD79a and BCL2 were studied. Variable expression was noted on the two B-cell markers CD20 and CD79a, with CD20 showing more consistent and strong expression; this result also agreed by others. ${ }^{11,18} \mathrm{CD} 79 \alpha$ had also been detected in 10 to $50 \%$ of precursor T-cell acute lymphoblastic lymphoma making this marker less reliable as an indicator of B-cell lineage. ${ }^{19}$ Furthermore, CD3 was the most commonly used pan-T-cell antigen but natural killer cells can also express CD3. ${ }^{18}$ Marginal zone lymphoma, follicular lymphoma and some diffuse large cell lymphoma are BCL-2 positive and also BCL-2 expression was variable geographically. ${ }^{18}$ These factors lead to the high BCL-2 expression found in this study. In addition, it should always be remembered that no antigen is totally specific; therefore immunostaining must be interpreted in the context of a panel to avoid errors. ${ }^{18}$

\section{Conflicts of interest}

The authors report no conflicts of interest.

\section{Conclusion}

Most NHLs were of B cell type and highest percentage is of diffuse large cell type.
CD20 and CD3 were more reliable as an indicator of $B$ \& $T$ cell lineage, respectively. Most NHLs were of intermediate-high grade. Nodal site represent highest rate for primary NHL. Further study with long and short follow up of patients is a vital issue. It is also recommended to study the relations between immunohistochemical expressions and molecular genetics markers in different types of NHLs. Identifying such molecular markers can speed up diagnosis at early stage of life.

\section{References}

1. Michael W, Brunilda N, Hansa B, et al. Health wise. Non Hodgkin's lymphoma - Overview; 2010. Available from: http://www.webmd.com/ cancer/non-hodgkins-lymphoma/non-hodgkinslymphoma-topic-overview.

2. Dorland's Electronic Medical Dictionary. W.B. Saunders Company. $29^{\text {th }}$ Edition, Available from: http://www.mercksource.com/pp/us/cns/ cns_hl_dorlands_split. 2007

3. Iraqi Cancer Registry Team. Results of Iraqi Cancer Registry. Ministry of Health; 2005.

4. Othman RT, Abdulljabar R, Saeed A, Kittani SS, Sulaiman HM, Mohammed SA, et al. Cancer Incidence Rates in the Kurdistan Region/Iraq from 2007-2009. Asian Pacific J Cancer Prev 2011; 12: 1261-4.

5. Howlader N, Noone AM, Krapcho M, Neyman N, Aminou R, Waldron W et al. SEER Cancer Statistics Review, National Cancer Institute. Bethesda, MD. Available from: http:// seer.cancer.gov/csr/1975_2008/, posted to the SEER web site. 2011.

6. Ferlay J, Shin HR, Bray F, Forman D, Mathers C, Parkin DM. Cancer incidence and mortality worldwide: IARC Cancer Base No. 10. GLOBOCAN 2008. Lyon: International Agency for Research on Cancer; 2010.

7. Burton C, Jack A, Adamson P, Roman E. Descriptive epidemiology. In: Magrath IT, editor. The Lymphoid Neoplasms. $3^{\text {rd }}$ edition. London: Hodder Arnold; 2010. P. 47-58.

8. Greiner TC, Medeiros LJ, Jaffe ES. Non-Hodgkin's lymphoma. Cancer 1995;75: 370-80.

9. Harris NL, Jaffe ES, Diebold J, Flandrin G, Muller-Hermelink HK, Vardiman J, et al. World Health Organization classification of neoplastic diseases of the hematopoietic and lymphoid tissues: report of the Clinical Advisory Committee meeting-Airlie House, Virginia, November 1997. J Clin Oncol 1999;17(12):3835-49.

10. Working_Formulation. Available from: http://en.wikipedia.org/wiki/. 2013. 
11. Talaulikar D, Dahlstrom J, Shadbolt B, Broomfield A, McDonald A. Role of Immunohistochemistry in Staging Diffuse Large B-cell Lymphoma (DLBCL). JHC 2008; 56(10): 893-900.

12. Mattoch IW, Fulton R, Kim Y, Hoppe R, Warnke RA, Sundram UN. Cutaneous Peripheral T-Cell Lymphoma Associated With a Proliferation of B Cells. Am J Clinical Pathol2009; 131: 810-9.

13. Jaffe ES, Harris, NL, Stein $H$ Vardiman, JW. Pathology and Genetics of Tumors of Hematopoietic and Lymphoid Tissues. Lyon, France: IARC Press. World Health Organization Classification of Tumors; Vol 3. 2001.

14. Yaqo RT, Hughson MD, Sulayvani FK, Al-Allawi NA. Malignant lymphoma in northern Iraq: A retrospective analysis of 270 cases according to the World Health Organization classification. Indian Journal of Cancer. Hematological Malignancies 2011;48:4 446-51

15. Kalyan K, Basu D, Soundararaghavan, J. Immunohistochemical typing of non-Hodgkin's lymphoma-comparing working formulation and WHO classification. Indian J Pathol Microbiol 2006 ;49(2):203-7.

16. Jaffe ES, Harris NL, Stein H, Vardiman JS. World Health Organization Classification of Tumours. Pathology and Genetics. Tumours of Haematopoietic and Lymphoid Tissues. Lyon: IARC press; 2001.

17. Abdel-Ghafar AA, El Din El Telbany MA, Mahmoud HM, El-Sakhawy YN . Immunophenotyping of chronic B-cell neoplasms: flow cytometry versus immunohistochemistry. Hematol 2012; 2(4):1.

18. Higgins RA, Blankenship JE, Kinney MC. Application of Immunohistochemistry in the Diagnosis of Non-Hodgkin and Hodgkin Lymphoma. Archives of Pathology \& Laboratory Medicine 2008; 132(3): 441-61.

19. Pilozzi E, Pulford K, Jones M, Muller-Hermelink HK, Falini B, Ralfkiaer E, et al. Co-expression of CD79a (JCB117) and CD3 by lymphoblastic lymphoma. J Pathol 1998; 186:140-3. 